\title{
STUDI KASUS PENERAPAN KODE ETIK JURNALISTIK PADA BERITA SIBER YANG DIBAGIKAN MELALUI GRUP FACEBOOK "METRO BALI"
}

\author{
Kadek Wiramarta \\ STAHN Mpu Kuturan Singaraja \\ J1. Kresna Gg. III No. 2B Singaraja \\ Email: wiramartakadek@gmail.com
}

\begin{abstract}
This research is aimed at knowing (a) the sinchronization of the news spread by facebook group Metro Bali with the Ethic Code of Journalistics and (b) awareness level of social media users in Bali about journalism's news standard in the form of Ethic Code of Journalistics. To achieve this goal, 35 cyber news in "Metro Bali" was used by using purposive sampling technique. Other than that, there are 62 social media users chosen by random sampling technique. On this research, news cyber media in facebook group "Metro Bali" was observed by using checklist of Ethic Code of Journalistics as instruments. The comments on news sample were also observed to see the reaction of social media users on the shared cyber news. Other than that, social media users are given questionnaires. The collected data were analyzed quantitatively and qualitatively.

The result of this research shows that (a) there are still many news that haven 't met the standards of Ethic Code of Journalistics and (b) there are still many social media users who haven't tried to synchronize the news' contents with the Ethic Code of Journalistics. This research is expected at improving the society's awareness to be wise social media readers and users especially on the issue of cyber news.
\end{abstract}

Keywords : Cyber News, Journalistic Ethic Code, Social Media

\begin{abstract}
ABSTRAK
Penelitian ini bertujuan untuk mengetahui (a) kesesuaian berita yang disebar melalui grup $\mathrm{Fa}$ cebook Metro Bali dengan kode etik jurnalistik dan (b) tingkat kesadaran pengguna media sosial di Bali tentang standar berita pers berupa kode etik jurnalistik. Untuk mencapai tujuan ini, 35 berita siber pada grup "Metro Bali" dipilih dengan menggunakan teknik purposive sampling. Selain itu, terdapat 62 pengguna media sosial yang dipilih secara acak sebagai sampel. Pada penelitian ini, berita media siber di grup facebook "Metro Bali" diobservasi dengan menggunakan ceklis kode etik jurnalistik sebagai instrumen. Komentar pada sampel berita juga turut diobservasi untuk melihat reaksi pengguna sosial media terhadap berita siber yang dibagikan. Selain itu, pengguna sosial media diberikan sebuah kuesioner. Data yang terkumpul nantinya dianalisa secara kuantitatif dan kualitatif.

Hasil penelitian menunjukkan bahwa (a) masih banyak berita yang masih belum memenuhi standar kode etik jurnalistik dan (b) masih banyak pengguna media sosial yang tidak berusaha mencari tahu kesesuaian konten berita dengan kode etik jurnalistik. Penelitian ini diharapkan dapat meningkatkan kesadaran masyarakat untuk menjadi pembaca dan pengguna media sosial yang bijak terutama dalam masalah berita siber.
\end{abstract}

Kata kunci : berita siber, kode etik jurnalistik, media sosial 


\section{PENDAHULUAN}

Jaminan akan kebebasan mendapatkan informasi dan pentingnya informasi pada perkembangan ilmu pengetahuan membuat persebaran informasi dituntut semakin cepat. Melihat peluang ini, berbagai media masa berlomba-lomba membuat berita-berita informatif yang dapat diakses secara fleksibel kapanpun dan di manapun. Oleh karena itu media masa kini memuat beritanya pada situs internet yang sering disebut dengan media massa siber. Dapat dikatakan, perkembangan jurnalisme media siber saat ini semakin pesat. Kehadirannya pun semakin diminati oleh masyarakat. Kecepatan (aktualitas) dan kemudahan akses pemberitaan yang ditawarkan melalui portal-media masa siber menjadikan media ini kian populer di masyarakat.

Secara sederhana, media siber dapat didefinisikan sebagai alat komunikasi dengan menggunakan jaringan internet atau bentuk komunikasi yang ada di dunia maya (Maulidi, 2016). Dengan kata lain, secara harfiah, meledaknya fenomena media siber tidak terlepas dari pengaruh luasnya pemakaian internet. Di Indonesia, dalam lima tahun terakhir, pengakses internet terus melonjak seiring dengan ketersediaan infrastruktur yang makin meluas, terjangkau, dan murah.

Sayangnya, dengan keunggulan yang dimiliki oleh media massa internet ini, tidak membuat media massa internet menjadi yang paling sempurna (Margianto dan Syaefulah, 2014). Ada banyak hal yang masih perlu dievaluasi dalam bisnis media yang sarat teknologi ini. Masalah pokok dalam dunia jurnalisme media internet adalah kualitas dan kredibilitas informasi yang sampai ke masyarakat. Atas nama kecepatan, page view, dan pertumbuhan bisnis, acapkali lembaga berita online terjerembab menyampaikan informasi yang belum final terverifikasi kepada masyarakat luas sehingga terkadang menimbulkan mispersepsi dan mis-interpretasi fakta. Laporan yang masuk ke Dewan Pers mengenai keluhan berita di media massa siber jumlahnya terus meningkat. Letak kesalahan lebih banyak karena masalah akurasi informasi yang dipaparkan lembaga media online. Data dari Dewan Pers ini bukan sekedar statistik, tapi sudah lebih pada peringatan bahwa harus ada yang dibenahi dalam tubuh institusi media massa internet.

Selain permasalahan tersebut di atas, Masduki (2003:19) mengungkapkan bahwa keinginan masyarakat yang menghendaki untuk mendapatkan informasi berupa berita yang tidak biasa-biasa saja, ditambah tekanan kuat dari pemilik modal, telah membuat jurnalis bersikap pragmatis. Sikap jurnalis ini terlihat kurang profesional. Mereka cenderung membuat berita-berita yang hanya menekankan pada unsur sensasional semata, dengan tujuan agar berita itu cepat laku di pasaran tanpa mengedepankan akurasi serta keberimbangan dalam berita. Dibandingkan dengan membuat berita yang benar, jurnalis sering memberi bumbu yang cenderung membuat berita itu menarik namun makin jauh dari fakta yang ada di lapangan. Padahal akurasi dan keberimbangan merupakan syarat berita yang wajib dipenuhi oleh jurnalis dalam membuat berita.

Lebih gawat lagi, adanya fitur sharing yang terdapat pada beberapa media sosial. Setiap orang yang memiliki media sosial mampu menggunakan fitur sharing di sosial media dan menyebarkan informasi yang terdapat pada media massa siber ini. Sayangnya banyak berita-berita yang sensasional dan jauh dari fakta ini tidak luput dari fitur ini. Banyak pengguna sosial media menyebarkan berita-berita ini pada follower mereka di sosial media. Hal ini menyebabkan persebaran berita yang sensasional inipun semakin cepat.

Keterkaitan media massa siber dan media sosial tentu memiliki beberapa kekurangan. Pertama, media sosial cenderung memiliki agenda tersendiri (Macnamara dalam Krisdiyanti, 2013). Setiap pemilik akun media sosial memiliki pandangan mereka sendiri dalam melihat masalah. Akibatnya, berita siber yang mereka sebarkan cenderung bersifat sepihak dan tidak berimbang. Kedua, Guntarto (2014) menyatakan bahwa tidak semua pengguna sosial media memiliki literasi yang cukup sehingga memiliki kesadaran, kendali, dan batasan yang jelas dalam menyebarkan berita melalui media sosial. Akibatnya, informasi simpang 
siur bertebaran lewat akun-akun sosial media ini. Di sinilah literasi media memiliki peran penting sehingga masyarakat dapat menggunakan media sosial secara proporsional.

Sementara itu Dewan Pers Indonesia sebagai lembaga yang melindungi kebebasan pers sekaligus melakukan pengkajian untuk pengembangan kehidupan pers dan menetapkan dan mengawasi pelaksanaan kode etik jurnalistik telah berupaya untuk membuat standar berita yang layak disebut sebagai produk pers. Dalam sebuah harian di Republika pada tanggal 6 April 2015 Dewan Pers Indonesia menyatakan bahwa tulisan dianggap sebagai produk pers apabila telah memenuhi kode etik jurnalistik sebagai pedoman penulisan. Menurut Dewan Pers Indonesia (2011) kode etik jurnalistiklah yang akan menjadi landasan moral dan etika profesi sebagai pedoman operasional dalam menjaga kepercayaan publik dan menegakkan integritas serta profesionalisme

Mempertimbangkan latar belakang di atas, penulis tertarik untuk melihat fenomena berita yang di-share melalui sosial media. Penulis tertarik untuk melihat kesesuaian konten berita yang disebar melalui sosial media dengan kode etik jurnalistik. Selain itu penulis ingin mengetahui apakah pengguna sosial media sudah cukup dewasa dalam menyikapi berita media massa siber yang disebarkan melalui media sosial.

Untuk mencapai tujuan ini, maka penulis melakukan analisa pada grup facebook yang terdapat di Bali. Objek yang dipilih dalam penelitian ini adalah grup Metro Bali. Grup facebook ini memiliki audiens yang cukup banyak dan seringkali anggota grup menyebarkan beberapa berita online yang dimuat pada grup ini.

Berdasarkan uraian di atas, maka peneliti tertarik untuk melakukan penelitian yang bertujuan untuk mengetahui tingkat kesesuaian berita yang disebar melalui grup facebook Metro Bali dengan kode etik jurnalistik dan (b) tingkat kesadaran pengguna media sosial di Bali tentang kode etik jurnalistik.

\section{METODE}

Desain dari penelitian ini adalah metode campuran (mixed method) tipe Sequential Explanatory. Karakter penelitian tipe ini adalah pengkoleksian dan analisa data kuantitatif yang diikuti oleh kualitatif (Cresswell, 2003). Hal ini biasanya berguna dalam memperdalam alasan dan interpretasi dari sebuah penelitian kuantitatif.

Secara garis besar penelitian ini mengambil 2 sampel penelitian. Pertama, peneliti memilih beberapa sampel berita yang disebar melalui grup facebook Metro Bali. Berita yang dikumpulkan berasal dari berita yang dibagikan pada tanggal 10 Agustus, 11 Agustus, 9 September, 10 September, 11 September, 12 September dan 14 September 2016. Untuk mengambil sampel penelitian ini, terdapat beberapa pertimbangan tertentu yang digunakan. Pertimbangan tersebut adalah (a) Berita yang telah direspon (like, wow, sad, angry, dll.) minimal sebanyak 10 kali; (b) berita mendapatkan minimal 5 komentar dan (c) berita disebarkan minimal sebanyak 5 kali oleh anggota grup keluar dari grup tersebut. Dari beberapa ketentuan tersebut, didapatkan 35 berita yang akan dianalisa.

Sedangkan sampel kedua adalah para pengguna media sosial di Bali. Untuk mencari sampel, maka metode sampling acak digunakan. Sampel dicari dengan menyebarkan instrumen secara acak melalui media sosial dan akhirnya didapatkan 62 sampel responden untuk penelitian. Untuk mencapai tujuan penelitian, observasi dan pemberian kuesioner pada sampel dilakukan. Metode observasi dilakukan kepada berita siber yang disebar melalui media sosial untuk melihat keterpenuhan standar berita siber berdasarkan kode etik jurnalistik. Observasi juga dilakukan pada kolom komentar untuk melihat reaksi para pengguna media sosial ketika membaca berita siber. Selain itu, peneliti juga menyebarkan kuesioner kepada responden secara online untuk mengetahui tingkat literasi media pengguna sosial.

Analisa data dilakukan dengan cara 
deskriptif kuantitaf dan kualitatif. Analisa data dilakukan setelah mendapatkan data baik dari hasil kuesioner maupun dari hasil observasi. Kemudian data tersebut diolah dan dianalisa dan dibuat dalam bentuk tabel dan grafik agar lebih mudah dimengerti.

\section{HASIL DAN PEMBAHASAN}

Untuk kesesuaian isi berita dengan kode etik jurnalistik, maka sebuah ceklis observasi dibuat. Dewan Pers Indonesia menjabarkan bahwa terdapat 11 pasal dan 34 tafsiran yang ada pada kode etik jurnalistik. Namun karena berbagai alasan, hanya terdapat 7 pasal dan 14 tafsiran yang bisa diukur melalui penelitian ini. Berdasarkan hasil analisa dari 7 pasal dan 14 tafsiran tersebut maka diperoleh hasil seperti di bawah ini.

Gambar 1. Tingkat kesesuaian berita dengan kode etik jurnalistik
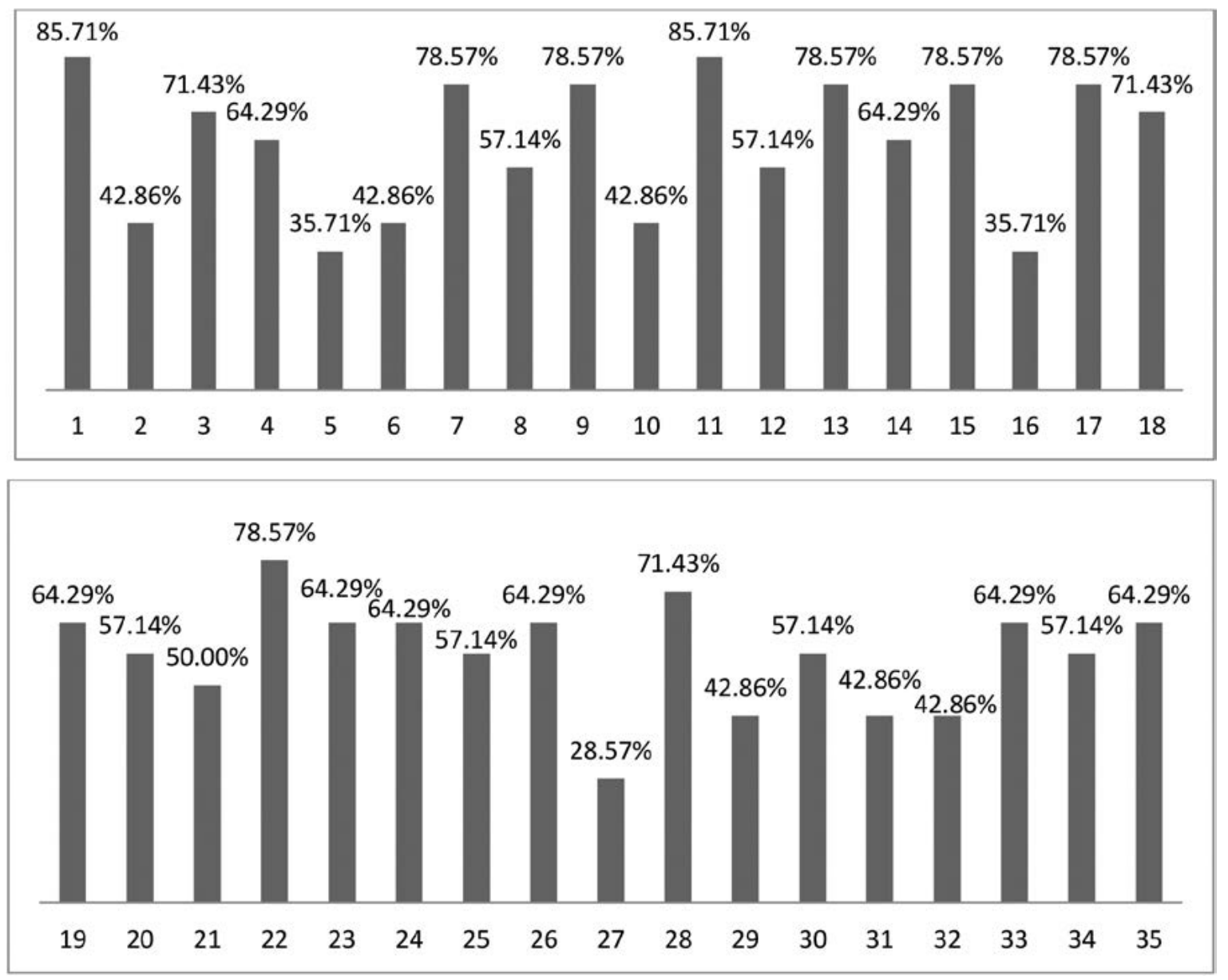

Berdasarkan grafik di atas, dapat dilihat bahwa tingkat kesesuaian konten berita dengan kode etik jurnalistik cukup beragam. Tingkat kesesuaian terendah terletak pada berita nomor 27 dengan $28,57 \%$. Sedangkan tingkat kesesuaian tinggi terdapat pada berita nomor 1 dan berita nomor 11 dengan $85,71 \%$. Jika dirata-ratakan, tingkat kesesuaian berita dengan kode etik jurnalistik adalah $60,61 \%$.

Sementara itu, jika dilihat dari tingkat keterpenuhan masing-masing kode etik maka hasil yang didapat dapat dilihat pada grafik berikut. 
Tabel 1. Tingkat keterpenuhan masing-masing kode etik jurnalistik

\begin{tabular}{|c|c|c|c|c|}
\hline No & Kode Etik Jurnalistik & & Tafsiran & $\begin{array}{l}\text { Jumlah } \\
\text { berita yang } \\
\text { memenuhi } \\
\text { Kriteria }\end{array}$ \\
\hline 1 & $\begin{array}{l}\text { Wartawan Indonesia } \\
\text { bersikap independen, } \\
\text { menghasilkan berita yang } \\
\text { akurat, berimbang, dan } \\
\text { tidak beritikad buruk. }\end{array}$ & c. & $\begin{array}{l}\text { Berimbang berarti semua pihak } \\
\text { mendapat kesempatan setara. }\end{array}$ & $11,43 \%$ \\
\hline \multirow{4}{*}{2} & \multirow{4}{*}{$\begin{array}{l}\text { Wartawan Indonesia } \\
\text { menempuh cara-cara } \\
\text { yang profesional dalam } \\
\text { melaksanakan tugas } \\
\text { jurnalistik. }\end{array}$} & d. & $\begin{array}{l}\text { menghasilkan berita yang faktual dan } \\
\text { jelas sumbernya; }\end{array}$ & $62,86 \%$ \\
\hline & & e. & $\begin{array}{l}\text { rekayasa pengambilan dan pemuatan } \\
\text { atau penyiaran gambar, foto, suara } \\
\text { dilengkapi dengan keterangan tentang } \\
\text { sumber dan informasi yang } \\
\text { ditampilkan; }\end{array}$ & $31,43 \%$ \\
\hline & & f. & $\begin{array}{l}\text { menghormati pengalaman traumatik } \\
\text { narasumber dalam penyajian gambar, } \\
\text { foto, suara; }\end{array}$ & $74,29 \%$ \\
\hline & & g. & $\begin{array}{l}\text { tidak melakukan plagiat, termasuk } \\
\text { menyatakan hasil liputan wartawan lain } \\
\text { sebagai karya sendiri; }\end{array}$ & $71,43 \%$ \\
\hline \multirow[b]{2}{*}{3} & \multirow[b]{2}{*}{$\begin{array}{l}\text { Wartawan Indonesia } \\
\text { selalu menguji informasi, } \\
\text { memberitakan secara } \\
\text { berimbang, tidak } \\
\text { mencampurkan fakta dan } \\
\text { opini yang menghakimi, } \\
\text { serta menerapkan asas } \\
\text { praduga tak bersalah. }\end{array}$} & a. & $\begin{array}{l}\text { Menguji informasi berarti melakukan } \\
\text { check and recheck tentang kebenaran } \\
\text { informasi itu. }\end{array}$ & $28,57 \%$ \\
\hline & & c. & $\begin{array}{l}\text { Opini yang menghakimi adalah } \\
\text { pendapat pribadi wartawan. Hal ini } \\
\text { berbeda dengan opini interpretatif, } \\
\text { yaitu pendapat yang berupa interpretasi } \\
\text { wartawan atas fakta. Opini yang dibuat } \\
\text { tidak langsung menyalahkan seseorang } \\
\text { dan tetap pada asas praduga tak } \\
\text { bersalah }\end{array}$ & $77,14 \%$ \\
\hline \multirow{3}{*}{4} & \multirow{3}{*}{$\begin{array}{l}\text { Wartawan Indonesia } \\
\text { tidak membuat berita } \\
\text { bohong, fitnah, sadis, dan } \\
\text { cabul. }\end{array}$} & c. & $\begin{array}{l}\text { Sadis berarti kejam dan tidak mengenal } \\
\text { belas kasihan. }\end{array}$ & $85,71 \%$ \\
\hline & & d. & $\begin{array}{l}\text { Cabul berarti penggambaran tingkah } \\
\text { laku secara erotis dengan foto, gambar, } \\
\text { suara, grafis atau tulisan yang semata- } \\
\text { mata untuk membangkitkan nafsu } \\
\text { birahi. }\end{array}$ & $88,57 \%$ \\
\hline & & e. & $\begin{array}{l}\text { Dalam penyiaran gambar dan suara } \\
\text { dari arsip, wartawan mencantumkan } \\
\text { waktu pengambilan gambar dan suara. }\end{array}$ & $17,14 \%$ \\
\hline 5 & $\begin{array}{l}\text { Wartawan Indonesia } \\
\text { tidak menyebutkan dan } \\
\text { menyiarkan identitas } \\
\text { korban kejahatan susila } \\
\text { dan tidak menyebutkan } \\
\text { identitas anak yang } \\
\text { menjadi pelaku } \\
\text { kejahatan. }\end{array}$ & a. & $\begin{array}{l}\text { Identitas adalah semua data dan } \\
\text { informasi yang menyangkut diri } \\
\text { seseorang yang memudahkan orang } \\
\text { lain untuk melacak. }\end{array}$ & $80,00 \%$ \\
\hline 8 & $\begin{array}{l}\text { Wartawan Indonesia } \\
\text { tidak menulis atau } \\
\text { menyiarkan berita } \\
\text { berdasarkan prasangka }\end{array}$ & a. & $\begin{array}{l}\text { Tidak Menyebarkan anggapan yang } \\
\text { kurang baik mengenai sesuatu sebelum } \\
\text { berita tersebut jelas }\end{array}$ & $37,14 \%$ \\
\hline
\end{tabular}




\begin{tabular}{|c|l|c|l|c|}
\hline $\begin{array}{l}\text { atau diskriminasi } \\
\text { terhadap seseorang atas } \\
\text { dasar perbedaan suku, } \\
\text { ras, warna kulit, agama, } \\
\text { jenis kelamin, dan bahasa } \\
\text { serta tidak merendahkan } \\
\text { martabat orang lemah, } \\
\text { miskin, sakit, cacat jiwa } \\
\text { atau cacat jasmani. }\end{array}$ & b. & Tidak ada perbedaan perlakuan & $94,29 \%$ \\
\hline 9 & $\begin{array}{l}\text { Wartawan Indonesia } \\
\text { menghormati hak } \\
\text { narasumber tentang } \\
\text { kehidupan pribadinya, } \\
\text { kecuali untuk } \\
\text { kepentingan publik. }\end{array}$ & b. & $\begin{array}{l}\text { Kehidupan pribadi adalah segala segi } \\
\text { kehidupan seseorang dan keluarganya } \\
\text { selain yang terkait dengan kepentingan } \\
\text { publik. }\end{array}$ & $88,57 \%$ \\
\hline
\end{tabular}

Berdasarkan tabel di atas,dapat dilihat bahwa jenis kode etik yang paling banyak dipenuhi persyaratannya adalah kode etik pasal 8 tafsiran B dengan 94,29\%. Sedangkan terdapat 5 pasal dan tafsiran di mana pemenuhannya di bawah 50\%. Kelima, pasal tersebut adalah pasal 1 tafsiran C, pasal 4 tafsiran E, pasal 3 tafsiran A, pasal 2 tafsiran E dan pasal 8 tafsiran A.

Dalam rangka mencari data mengenai kesadaran pengguna media sosial tentang standar berita pers, kuesioner online dilakukan. Beberapa data didapatkan melalui metode ini. Data di bawah ini akan menunjukkan kesadaran pembaca mengenai eksistensi kode etik jurnalistik.

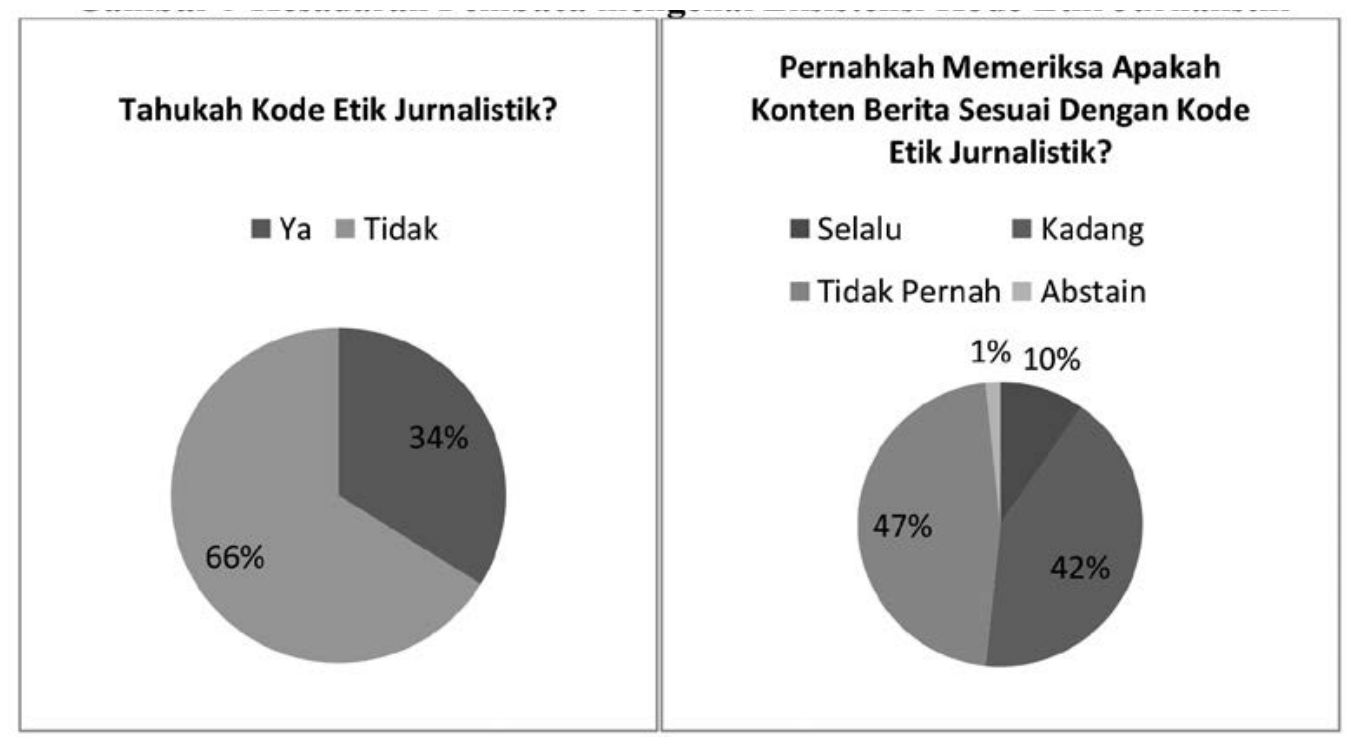

Gambar 2. Kesadaran pembaca mengenai eksistensi kode etik jurnalistik

Berdasarkan gambar diagram di atas, dapat dilihat bahwa mayoritas responden tidak mengetahui tentang kode etik jurnalistik. Sebanyak 66\% Responden (41 orang) menyatakan bahwa mereka tidak mengetahui atau mengerti tentang kode etik jurnalistik. Sedangkan $34 \%$ sisa responden (21 orang) menyatakan pernah mendengar dan mengerti tentang kode etik jurnalistik.

Poin berikutnya mempertanyakan apakah responden pernah mempertanyakan kesesuaian konten berita dengan kode etik jurnalistik. Dari 62 responden sebanyak 47\% responden ( 29 orang) menyatakan bahwa mereka tidak pernah mengecek kesesuaian konten berita dengan kode etik jurnalistik. Sementara itu, $42 \%$ responden(26orang) menyatakan bahwa mereka pernah mengecek 
konten berita berdasarkan kode etik jurnalistik. Di lain pihak, hanya terdapat $10 \%$ responden (6 orang) yang selalu mengkritisi jika konten berita tidak sesuai dengan kode etik jurnalistik.

Dari hasil di atas, mayoritas responden masih belum memiliki pengetahuan tentang kode etik jurnalistik ataupun berusaha mencocokkan, mengevaluasi atau mengklarifikasi konten berita berdasarkan kode etik jurnalistik.

Untuk mengkonfirmasi hasil kuesioner ini, maka observasi pada komentar-komentar yang ada di sampel perlu dilakukan. Tujuan observasi adalah untuk mengetahui jika ada dari pembaca berita tersebut berusaha mengklarifikasi atau mengevaluasi konten/sumber berita yang diposkan di laman facebook. Hasil dari observasi tersebut dapat dilihat pada tabel di bawah ini.

Tabel 2. Respon anggota Metro Bali terhadap keabsahan sumber.

\begin{tabular}{|c|c|c|c|}
\hline \multirow[t]{2}{*}{ No Berita } & \multirow[t]{2}{*}{ Jumlah Komentar } & \multicolumn{2}{|c|}{$\begin{array}{c}\text { Respon terhadap Keabsahan } \\
\text { Sumber }\end{array}$} \\
\hline & & Mempertanyakan & Tidak \\
\hline 1 & 30 & 0 & 30 \\
\hline 2 & 73 & 0 & 73 \\
\hline 3 & 20 & 0 & 20 \\
\hline 4 & 26 & 0 & 26 \\
\hline 5 & 183 & 4 & 179 \\
\hline 6 & 5 & 0 & 5 \\
\hline 7 & 20 & 2 & 18 \\
\hline 8 & 19 & 4 & 15 \\
\hline 9 & 7 & 0 & 7 \\
\hline 10 & 84 & 0 & 84 \\
\hline 11 & 25 & 0 & 25 \\
\hline 12 & 166 & 0 & 166 \\
\hline 13 & 46 & 0 & 46 \\
\hline 14 & 45 & 0 & 45 \\
\hline 15 & 74 & 0 & 74 \\
\hline 16 & 15 & 0 & 15 \\
\hline 17 & 11 & 0 & 11 \\
\hline 18 & 30 & 0 & 30 \\
\hline 19 & 99 & 0 & 99 \\
\hline 20 & 12 & 0 & 12 \\
\hline 21 & 20 & 0 & 20 \\
\hline 22 & 52 & 0 & 52 \\
\hline 23 & 24 & 0 & 24 \\
\hline 24 & 10 & 0 & 10 \\
\hline 25 & 45 & 0 & 45 \\
\hline 26 & 107 & 3 & 104 \\
\hline 27 & 56 & 0 & 56 \\
\hline 28 & 113 & 0 & 113 \\
\hline 29 & 23 & 0 & 23 \\
\hline 30 & 42 & 0 & 42 \\
\hline
\end{tabular}




\begin{tabular}{|c|c|c|c|}
\hline 31 & 20 & 0 & 20 \\
\hline 32 & 12 & 3 & 9 \\
\hline 33 & 60 & 0 & 60 \\
\hline 34 & 81 & 0 & 81 \\
\hline 35 & 7 & 1 & 6 \\
\hline Rekapitulasi & 1662 & $1,02 \%$ & $98,98 \%$ \\
\hline
\end{tabular}

Dari tabel di atas dapat dilihat bahwa dari 1662 komentar yang diajukan pada 35 berita yang diposkan pada grup Metro Bali, hanya $1,02 \%$ nya saja yang mengkritisi berita tersebut. Sedangkan $98,98 \%$ dari jumlah komentar hanya memberikan komentar biasa, atau bahkan terlibat dalam debat pada kolom komentar untuk topik tersebut.

Ketika ditelisik lebih lanjut mengenali alasan seorang pengguna media sosial menyebarkan sebuah berita siber, kriteria yang menjadi prioritas pembaca dalam membagikan berita online yang dibaca dapat dilihat pada gambar berikut.

Gambar 3. Kriteria prioritas pembaca dalammembagikan berita online

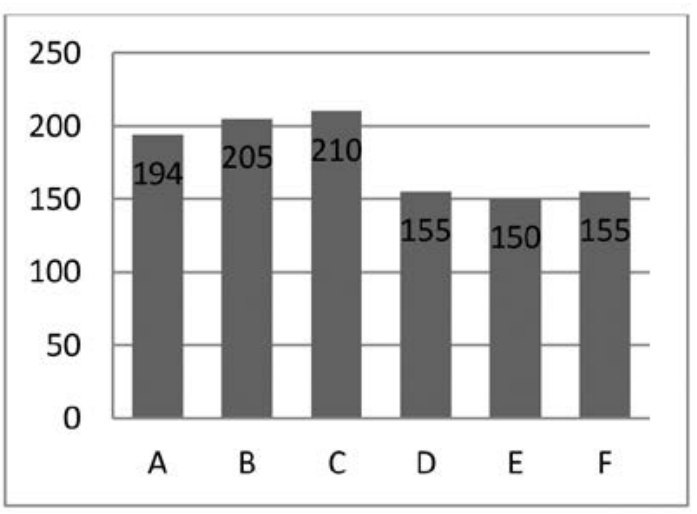

\section{Keterangan:}

a. Konten berita sesuai dengan pandangan saya mengenai suatu permasalahan

b. Konten berita menarik untuk didiskusikan dengan teman-teman saya

c. Konten berita penting untuk diketahui oleh follower atau teman saya di media sosial

d. Konten berita unik dan lucu sehingga dapat menghibur

e. Berita berasal dari portal online yang ter- akreditasi dan memenuhi standar kode etik jurnalistik

f. Berita berasal dari situs yang saya percaya

Berdasarkan data di atas, jika diurutkan, dapat dilihat bahwa pengguna media sosial masih menganggap bahwa pentingnya berita untuk diketahui oleh follower sebagai kriteria terpenting sebelum membagikan berita. Kemudian, kriteria berikutnya secara berurutan adalah konten berita menarik untuk didiskusikan dan konten berita sesuai dengan pandangan. Setelah itu, kriteria bahwa berita unik dan lucu serta berita berasal dari situs yang dipercaya pembaca berada di posisi yang sama. Akhirnya, apakah berita berasal dari portal online yang terakreditasi dan memenuhi standar kode etik jurnalistik masih menjadi prioritas terakhir dalam membagikan sebuah berita.

Dari kedua metode yang digunakan, dapat ditemukan bahwa pengetahuan masyarakat mengenai produk pers yang memenuhi kode etik jurnalistik masih dalam kategori rendah.

\section{PEMBAHASAN}

Setelah melalui proses analisa terdapat 2 kesimpulan yang didapatkan. Pertama, kesesuaian berita dengan penerapan kode etik jurnalistik Indonesia masih berada pada tahap yang kurang memuaskan. Selain itu, dapat terlihat bahwa pengetahuan masyarakat mengenai produk pers yang memenuhi kode etik jurnalistik masih dalam kategori rendah. Kedua hal ini secara umum membuktikan bahwa literasi media pada masyarakat dalam memilih berita yang dibagikan media sosial masih perlu ditingkatkan.

Perkembangan media siber yang begitu pesat merupakan dampak dari kebe- 
basan pers. Setiap orang berhak untuk menyebarkan berita yang mereka anggap benar. Sayangnya pembuat berita baru ini jarang sekali mendalami kode etik jurnalistik sebagai pedoman pembuatan berita. Ditambah lagi pemilik portal berita ini banyak juga yang memiliki agenda masing-masing dalam membuat beritanya. Akibatnya, banyak beritaberita yang berseliweran hanya dibuat secara asal-asalan dan sangat tidak berimbang.

Selain itu banyak juga portal berita siber yang mengejar keuntungan semata tanpa membuat berita yang benar. Media semacam ini mengejar klik pada berita yang disebarkan dengan membuat berita yang sensasional, cepat tapi tanpa berusaha untuk memverifikasi berita tersebut. Bagi mereka berita yang sensasional jauh lebih berharga dibandingkan kebenaran berita. Akibatnya berita yang dikembangkan masih jauh dari kata objektivitas.

Setelah melakukan analisa mendalam terhadap beberapa berita, ditemukan beberapa fenomena tidak wajar dalam berita yang dibagikan pada media sosial facebook grup "Metro Bali". Fenomena pertama yang ditemukan adalah banyaknya berita-berita yang tidak berimbang. Terdapat beberapa berita yang mengandalkan beberapa narasumber namun berada dalam satu sisi yang dapat mengurangi objektivitas berita tersebut. Lebih parah lagi, terdapat beberapa berita yang hanya mengandalkan satu narasumber yang membeberkan opininya dari satu sudut pandang saja. Bentuk-bentuk pemberitaan seperti ini jelas akan berdampak buruk pada opini masyarakat. Sebuah kebenaran mungkin saja ditutupi karena berita yang cenderung berat sebelah. Fakta yang harusnya muncul pada sebuah berita tidak dihiraukan lagi-lagi karena pemberitaan yang hanya memandang sebuah fenomena dari satu sisi. Ketidakberimbangan berita membentuk opini publik yang kemungkinan besar akan memihak satu sisi saja. Contoh saja pada berita yang berjudul Komisi III DPR Akan Laporkan ForBali Ke Polri. Berita ini memberitakan pelanggaran dari salah satu organisasi A karena telah menurunkan bendera di gedung DPRD Bali dan menganggap aksi ini sebagai bentuk perendahan bendera Sang
Merah Putih. Pada berita ini, narasumber yang digunakan hanyalah satu orang yakni seorang Bapak-bapak anggota Komisi III DPR dengan inisial R. S. Yang perlu diingat adalah sebuah wawancara dengan satu narasumber tidak mewakilkan keseluruhan anggota Komisi III DPR. Terlebih, tidak terdapat narasumber lain dari pihak yang berada di pihak berseberangan untuk menyampaikan pendapat mereka. Bentuk pemberitaan ini akan membentuk opini publik bahwa apa yang dilakukan oleh organisasi A adalah sebuah kesalahan tanpa mengetahui apa motif atau apa yang terjadi pada hari itu menurut versi Organisasi A. Atau di lain pihak, organisasi A akan menganggap bahwa Komisi III DPR tidak mewakilkan aspirasinya tanpa tahu terlebih dahulu mengenai opini anggota lain dari Komisi III DPR.

Fenomena kedua yang muncul adalah tidak terlindunginya anak-anak atau korban pemerkosaan dalam pemberitaan. Pada beberapa berita, nama korban pemerkosaan atau pelaku kriminal anak disebutkan dengan jelas. Baik pelaku kriminal anak-anak maupun korban pemerkosaan masih memiliki masa depan yang harus mereka hadapi. Namun dengan kehadiran berita-berita siber ini, masa depan mereka harus dibayangi masa lalu yang gelap. Terlebih, berita siber ini biasanya lebih mudah diakses dan dapat diakses dalam waktu yang lama. Dengan demikian rasa trauma akan masa lalu yang gelap ini akan semakin berkepanjangan. Sebut saja pada kasus berita berjudul Bak-buk! Guru SMKN 2 Makassar Dipukul Orangtua Siswa di Ruang Kelas, pelaku pemukulan yang masih merupakan anak-anak terpampang dengan jelas. Di kasus lainnya, pada berita yang berjudul Parah...!! Aa Gatot Mengaku Dirasupi Jin Nabi Sulaiman Saat Berhubungan Badan dengan $C$. Pada berita ini, Huruf $C$ bukanlah merupakan judul sebenarnya. $\mathrm{C}$ adalah inisial nama korban pemerkosaan yang ditulis dengan lengkap di judul berita. Kedua permasalahan ini akan memberikan dampak traumatis yang cukup lama pada objek pemberitaan.

Fenomena pemberitaan lainnya yang muncul adalah pemberitaan yang bersifat SARA. Segala sesuatu yang bersifat SARA 
sangatlah sensitif karena bersangkutan dengan adanya keanekaragaman dan kemajemukan bangsa Indonesia yang menimbulkan adanya perbedaan pandangan maupun pendapat. Setiap orang tentunya mempunyai pandangan, pendirian maupun pendapat yang berbeda-beda, apalagi jika sudah menyangkut kepercayaan maupun adat serta budaya. Pemberitaan yang bersifat SARA jika tidak diberitakan dengan penuh kehati-hatian akan bisa menyulut kemarahan sebuah kaum dan berujung pada sebuah kerusuhan. Sayangnya berita ini masih sering menjadi berita yang disebar pada media sosial. Sebut saja pada kasus berita yang berjudul Kenapa Orang Kafir Sebaik Apapun Tetap Masuk Neraka? Jawaban Kyai ini Bikin Liberal Terbungkam. Berita ini menyatakan bahwa syarat untuk masuk surga adalah memasuki sebuah agama tertentu. Berita ini bisa menyulut kemarahan karena memvonis bahwa selain agama yang bersangkutan, agama lain tidak akan membuat orang masuk surga. Sayangnya, berita semacam ini tidak hanya dibagikan oleh orang dengan agama yang bersangkutan, tapi juga oleh provokator yang ingin memecah belah persatuan warga. Banyaknya pemberitaan ini dapat berdampak signifikan pada keutuhan sebuah bangsa jika dibiarkan secara berlarut-larut.

Kasus berikutnya berupa tidak adanya pengecekan ulang terhadap berita-berita di media sosial. Banyak berita yang dimunculkan hanya mengandalkan wawancara pada satu sumber saja tanpa berusaha mengecek sumber lain. Cara pengumpulan informasi juga seringkali hanya berupa wawancara saja tanpa berusaha mengobservasi kejadian sebenarnya. Pelanggaran kode etik ini berpotensi dapat membuat berita yang tidak sesuai fakta. Hasil wawancara pada satu narasumber tidak selalu merupakan representasi fakta di lapangan. Opini satu orang narasumber, walaupun orang yang memiliki kapabilitas di bidangnya, tidak lantas membuat berita tersebut menjadi objektif. Diperlukan lebih dari satu narasumber untuk mengkonfirmasi kebenaran sebuah berita. Sayangnya, berita-berita semacam ini masih sering dibagikan pada media sosial Bentuk fenomena selanjutnya yang muncul adalah permasalahan foto sebagai pelengkap berita. Terdapat beberapa permasalahan pada foto yang digunakan. Pertama, seringkali foto yang muncul pada berita tidak memberikan informasi pada berita tersebut. Fenomena ini memunculkan beberapa persepsi yang cenderung akan merugikan orang yang berada di foto. Sebut saja foto yang muncul pada berita Sok Jagoan Getok Kepala Pengamen Cilik, Polisi Hampir Jadi Bulan-Bulanan Warga. Pada foto tersebut terdapat gambar seorang polisi yang menghadapi kemarahan warga. Namun, karena tidak adanya informasi pada gambar, tidak jelas apakah foto yang digunakan merupakan foto asli dari kejadian tersebut atau hanya sebuah foto yang diambil secara sembarangan dan kebetulan cocok dengan isi berita. Jika disalahartikan, pembaca bisa saja menganggap bahwa polisi yang berada pada foto sebagai sosok polisi yang arogan walaupun terdpat kemungkinan bahwa foto tersebut berasal dari kejadian yang berbeda.

Fenomena yang masih berhubungan dengan foto adalah foto yang tidak menghormati rasa traumatis narasumber. Beberapa foto yang digunakan masih menampilkan kejadian yang membuat trauma. Sebut saja pada berita yang berjudul Bak, Buk, Guru SMKN 2 Makassar Dipukul Orang Tua Siswa di Ruang Kelas. Pada berita ini terdapat foto seorang korban dengan baju berbercak darah setelah dipukul oleh pelaku. Foto yang menampilkan korban dalam keadaan berdarah merupakan sebuah pengalaman traumatis bagi korban yang seharusnya tidak ditampilkan pada berita.

Fenomena lainnya yang masih berhubungan dengan foto adalah tidak disensornya beberapa foto yang cenderung akan mencemarkan nama baik seseorang. Sebut saja foto pada berita berjudul Parah...!! Aa Gatot Mengaku Dirasupi Jin Nabi Sulaiman Saat Berhubungan Badan dengan C. Pada foto tersebut, terpampang wajah $C$ sebagai korban pemerkosaan. Isu pemerkosaan adalah hal sensitif bagi wanita karena hal tersebut merupakan pengalaman yang traumatis baginya. Bagi beberapa masyarakat menjadi korban pemerkosaan adalah aib dan memalukan. Namun, penyebaran foto korban pemerkosaan 
ini menjadi salah satu bentuk ketidakhormatan pada privasi pelapor sebagai korban.

Fenomena lainnya yang tertangkap secara gamblang adalah terjadinya perang media antar satu portal berita siber dengan berita siber lainnya. Fenomena keberpihakan media dan perang antar media terjadi pada kasus yang paling sering diberitakan di Bali. Padahal untuk membuat berita itu berimbang dibutuhkan setidaknya dua narasumber dari dua sisi yang berbeda. Contoh saja pada berita tentang insiden penurunan bendera pada saat demonstrasi penolakan reklamasi. Namun setiap berita pada kedua sisi ini memiliki agenda masing-masing. Berita yang memberitakan tentang penangkapan anggota organisasi A menggiring opini publik seolaholah bahwa anggota organisasi ini melakukan kesalahan pelecehan bendera yang fatal tanpa mempertimbangan pendapat dari organisasi A. Di sisi lain berita mengenai permintaan untuk mencopot Bapak Kapolda Bali dibuat untuk menggiring opini masyarakat bahwa kasus ini merupakan sebuah kasus kriminalisasi pejuang organisasi A dan bahwa Bapak Kapolda sebagai bawahan investor tanpa mempertimbangkan pendapat Bapak Kapolda untuk dicantumkan pada berita tersebut. Kedua berita dari dua sisi yang berbeda seolah-olah saling menyerang dan saling menjawab satu sama lain. Yang sering dilupakan adalah, tidak semua orang akan membaca semua berita dari dua sisi yang berbeda. Persepsi yang muncul dari berita ini juga akan berbeda-beda

Fenomena menarik yang muncul lainnya adalah adanya berita yang berasal dari media sosial. Sebuah status, petisi atau gambar yang dibagikan pada sebuah sosial media seringkali menjadi objek pemberitaan. Sayangnya, berita-berita yang dibuat ini hanya menggunakan sumber media sosial sebagai sumber utama tanpa berusaha mengkonfirmasi kebenaran berita melalui proses cek dan ricek fakta di lapangan. Selain itu, fenomena ini sangat berpotensi menyebabkan permasalahan karena banyaknya terdapat akun palsu di media sosial yang menyebabkan ketidakvalidan berita yang diterima. Pada penelitian ini terdapat beberapa kasus di mana media sosial merupakan sumber utama berita. Berita-berita tersebut adalah Terjadi Lagi! Guru Ditonjok Orang Tua Murid, Diduga Akibat Fitnah Murid itu Sendiri. Pada berita ini, media siber hanya menggunakan salah satu akun facebook sebagai sumber utama. Padahal, belum tentu fenomena yang terekspos dalam satu sosial media merupakan fakta yang terjadi di lapangan. Hal ini tentu akan mengakibatkan kesalahan informasi yang beredar dan cenderung menyesatkan. Setidaknya, diperlukan sebuah proses turun ke lapangan untuk mengonfirmasi bahwa objek pemberitaan adalah fakta.

Fakta ini tidaklah mengejutkan. Ketidaktahuan warga akan kode etik jurnalistik menjadi alasan utama mengapa masyarakat jarang menggunakan standar ini sebelum membagikan berita. Berdasarkan kuesioner yang disebarkan, dari 62 responden hanya $66 \%$ responden mengetahui apa itu kode etik Jurnalistik dan hanya $10 \%$ yang selalu berusaha melihat berita dari sisi kode etik jurnalistik. Fakta ini menggambarkan bahwa sebagian besar responden masih tidak menyadari eksistensi kode etik jurnalistik sebagai standardisasi produk pers. Ketidaktahuan akan standardisasi produk pers ini seharusnya menjadi pengingat bahwa literasi pers di Indonesia masih perlu ditingkatkan lagi.

\section{PENUTUP}

\section{Kesimpulan}

Setelah melalui proses penelitian, dapat disimpulkan bahwa masih banyak berita yang masih belum memenuhi Kode Etik Jurnalistik. Jika dilihat dari rata-rata kesesuaian berita dengan beberapa kode pasal dan tafsiran kode etik jurnalistik yang dapat diukur, dapat dikatakan bahwa rata-rata, kesesuaian konten berita dengan beberapa poin pada kode etik jurnalistik adalah $60,61 \%$. Selain itu, jika dilihat dari masing-masing indikator, terdapat 5 pasal dan tafsiran di mana pemenuhan persyaratan kode etik jurnalistik di bawah $50 \%$. Kelima, pasal tersebut adalah pasal 1 tafsiran $\mathrm{C}$, pasal 4 tafsiran $\mathrm{E}$, pasal 3 tafsiran $\mathrm{A}$, pasal 2 tafsiran E dan pasal 8 tafsiran A.

Di lain pihak, masih banyak peng- 
guna media sosial tidak berusaha mencari tahu kesesuaian konten berita tentang kode etik jurnalistik atau Dewan Pers Indonesia. Dari 62 responden sebanyak 47\% responden (29 orang) menyatakan bahwa mereka tidak pernah mengecek kesesuaian konten berita dengan kode etik jurnalistik. Sementara itu, $42 \%$ responden ( 26 orang) menyatakan bahwa mereka pernah mengecek konten berita berdasarkan kode etik jurnalistik. Di lain pihak, hanya terdapat $10 \%$ responden ( 6 orang) yang selalu mengkritisi jika konten berita tidak sesuai dengan kode etik jurnalistik. Di sisi tedaftarnya situs berita siber di media siber, dari 62 responden, sebanyak 82\% (51 orang) tidak pernah mengecek apakah situs berita siber yang mereka baca di media sosial terdaftar atau terverifikasi di situs dewan pers. Sebanyak $13 \%$ (8 orang) menyatakan pernah mengecek situs berita di situs Dewan Pers Indonesia. Sisanya, sebanyak 5\% (3 orang) menyatakan selalu mengecek Situs Dewan Pers. Hasil penelitian ini menunjukkan bahwa masih banyak berita siber yang tersebar yang belum memenuhi standar yang ada. Hal ini semakin berbahaya dengan cukup rendahnya kesadaran pers dari para pengguna media sosial. Oleh karena itu pendidikan literasi media menjadi penting untuk dilakukan. Setidaknya, pembaca akan mendapatkan pengetahuan tentang bagaimana standar sebuah pemberitaan yang benar dan bagaimana menjadi seorang pembaca media masa siber yang bijak dan mampu memilah informasi yang pantas untuk disebarkan.

\section{DAFTAR PUSTAKA}

Creswell, J. W. 2003. Research design: Qualitative, quantitative, and mixed methods approaches (2nd ed.). Thousand Oaks, CA: Sage.

Dewan Pers Indonesia. 2011. Kode Etik Jurnalistik. Disadur dari http://www.dewan pers.or.id/peraturan/detail/190/kode-etik -jurnalistik pada 22 September 2016.

Guntarto, B. 2014. Catatan tentang Literasi Media. Disadur dari https://indonesia-media literacy.net. Diakses pada tanggal 23 September 2016.
Krisdiyanti, A.S. 2013. Pendahuluan. Disadur dari e-journal.uajy.ac.id/4280/2/1 KOM03825. pdf. Diakses pada tanggal 23 September 2016.

Margianto, J. Heru., Syaefullah, A. 2014. Media Online: Aliansi Jurnalis Independen. Disadur dari https://aji.or.id/upload/article _doc/Media_Online.pdf. Diakses pada 22 September 2016

Masduki. 2003. Kebebasan Pers dan Kode Etik Jurnalistik. Yogyakarta: UII Press . Maulidi, Achmad. 2016. Pengertian Media Siber (Cyber Media). Disadur dari http://www. kanalinfo.web.id/2016/09/ pengertian-media-siber-cyber-media.html diakses pada tanggal 23 September 2016. 